\title{
Correction to: a narrative review of economic Check for constructs in commonly used implementation and scale-up theories, frameworks and models
}

Vicki Brown ${ }^{1,2^{*}}$, Huong Tran ${ }^{1,2}$, Miranda Blake ${ }^{2}$, Rachel Laws ${ }^{3}$ and Marj Moodie ${ }^{1,2}$

\section{Correction to: Health Research Policy and Systems}

\section{(2020) 18:115}

https://doi.org/10.1186/s12961-020-00633-6

It was highlighted that in the original article the given and family name of the first author was interchanged and thus tagged incorrectly. This Correction article shows the correct name order. The original article has been updated.

\section{Publisher's Note}

Springer Nature remains neutral with regard to jurisdictional claims in published maps and institutional affiliations.

\section{Author details}

${ }^{1}$ Deakin Health Economics, Institute for Health Transformation, Deakin University, Geelong 3220, Australia. ${ }^{2}$ Global Obesity Centre, Institute for Health Transformation, Deakin University, Geelong 3220, Australia. ${ }^{3}$ Institute for Physical Activity and Nutrition, Deakin University, Geelong 3220, Australia.

Published online: 28 October 2020

The original article can be found online at https://doi.org/10.1186/s1296 1-020-00633-6.

*Correspondence: victoria.brown@deakin.edu.au

${ }^{1}$ Deakin Health Economics, Institute for Health Transformation, Deakin University, Geelong 3220, Australia

Full list of author information is available at the end of the article original author(s) and the source, provide a link to the Creative Commons licence, and indicate if changes were made. The images or other third party material in this article are included in the article's Creative Commons licence, unless indicated otherwise in a credit line to the material. If material is not included in the article's Creative Commons licence and your intended use is not permitted by statutory regulation or exceeds the permitted use, you will need to obtain permission directly from the copyright holder. To view a copy of this licence, visit http://creativecommons.org/licenses/by/4.0/. The Creative Commons Public Domain Dedication waiver (http://creativeco mmons.org/publicdomain/zero/1.0/) applies to the data made available in this article, unless otherwise stated in a credit line to the data. 